\title{
In vitro and In vivo Anti-cancer Effects of Tillandsia recurvata (Ball Moss) from Jamaica
}

\author{
HIC Lowe ${ }^{1,2,3}$, NJ Toyang ${ }^{2,3}$, J Bryant ${ }^{3}$
}

\begin{abstract}
Objective: Tillandsia recurvata, also commonly known as Ball Moss, is endemic to Jamaica and some parts of the Caribbean and South America. The plant, despite being reported to be used in folk medicine, had not previously been evaluated for its anti-cancer potential. The aim of this study was to evaluate the anti-cancer activity of Ball Moss.

Methods: The anti-proliferation activity of the crude methanolic extract of the $\mathrm{T}$ recurvata was evaluated in vitro in five different histogenic cancer cell lines (prostate cancer-PC-3, breast cancer, Kaposi sarcoma, B-16 melanoma and a B-cell lymphoma from a transgenic mouse strain) using the trypan blue assay. The crude extract was also evaluated in vivo in tumour-bearing mice. Immunohistochemistry staining with Apoptag was used for histology and determination of apoptosis.

Results: The crude methanolic extract of $\mathrm{T}$ recurvata demonstrated anti-proliferation activity against all the cell lines, killing $>50 \%$ of the cells at a concentration of $2.5 \mu \mathrm{g} / \mathrm{ml}$. Kaposi sarcoma xenograft tumours were inhibited by up to $75 \%$ compared to control in the in vivo study $(\mathrm{p}<0.05)$. There was evidence of DNA fragmentation and a decrease in cell viability on histological studies. The methanolic extract showed no toxic effect in the mice at a dose of $200 \mathrm{mg} / \mathrm{kg}$.

Conclusions: Our data suggest that $\mathrm{T}$ recurvata has great potential as an anti-cancer agent and that one of its mechanisms of cell kill and tumour inhibition is by the induction of apoptosis.
\end{abstract}

Keywords: Ball moss, cancer, medicinal plant, Tillandsia recurvata

\section{Efectos Anticancerosos In vitro e In vivo de la Tillandsia recurvata (Bola de Musgo) de Jamaica

\author{
HIC Lowe ${ }^{1,2,3}$, NJ Toyang ${ }^{2,3}$, J Bryant ${ }^{3}$
}

\begin{abstract}
RESUMEN
Objetivo: La Tillandsia recurvata, también conocida como bola de musgo, es endémica en Jamaica, así como en algunas partes del Caribe y América del sur. Si bien se había reportado su uso como parte de la medicina popular, esta planta no había sido evaluada previamente en relación con su potencial para la lucha contra el cáncer. El objetivo de este estudio fue evaluar la actividad anticancerígena de la bola de musgo.

Métodos: La actividad antiproliferativa del extracto metanólico crudo de la $\mathrm{T}$ recurvata, fue evaluada in vitro en cinco líneas celulares diferentes de cáncer histogenético (cáncer de próstata-PC-3, cáncer de mama, sarcoma de Kaposi, melanoma B-16 y un linfoma de células $B$ de una cepa de ratón transgénico) usando el ensayo con azul de tripano. El extracto crudo también se evaluó in vivo en ratones portadores de tumor. La tinción inmunohistoquímica con ApopTag fue utilizada para la histología y determinación de la apoptosis.

Resultados: El extracto metanólico crudo de T recurvata demostró la actividad proliferativa frente a todas las líneas celulares, matando $>50 \%$ de las células a una concentración de 2,5 $\mu \mathrm{g} / \mathrm{ml}$. Los tumores de xenoinjerto de sarcoma de Kaposi fueron inhibidos hasta un $75 \%$ en comparación con el control en el estudio in vivo $(\mathrm{p}<0.05)$. Hubo evidencia de fragmentación de DNA y una disminución
\end{abstract}

From: ${ }^{1}$ Bio-Tech R\&D Institute, Kingston, Jamaica, ${ }^{2}$ Educational and Scientific Corporation, Wellington, Florida, United States of America and ${ }^{3}$ Institute of Human Virology, University of Maryland School of Medicine, Baltimore, Maryland, United States of America.
Correspondence: Dr HIC Lowe, Bio-Tech R\& Institute, 44 Lady Musgrave Road, Kingston 10, Jamaica. E-mail: henrylowe@cwjamaica.com; lowe biotech@gmail.com 
en la viabilidad celular en los estudios histológicos. El extracto metanólico no mostró ningún efecto tóxico en los ratones a dosis de $200 \mathrm{mg} / \mathrm{kg}$.

Conclusiones: Nuestros datos sugieren que la $\mathrm{T}$ recurvata tiene gran potencial como agente anticanceroso, y que uno de sus mecanismos de inhibición de tumores y muerte de las células tiene lugar mediante la inducción de la apoptosis.

Palabras clave: Bola de moho, cáncer, plantas medicinales, Tillandsia recurvata

West Indian Med J 2013; 62 (3): 178

\section{INTRODUCTION}

Natural products are the most consistent successful source of drug leads (1-3). Plants supply most of the active ingredients of traditional medicinal products (4-6). The fight against cancer will continue to require the development of novel and improved chemotherapeutic agents. Drug discovery from plants involves a multidisciplinary approach combining botanical, ethnobotanical, phytochemical and biological technologies. Plants in particular have a long history of use in the treatment of cancer (7).

The genus Tillandsia is a group of epiphytic plants with approximately 500 species (8). There are no reports of traditional use of Ball Moss in Jamaica; however, the plant is used in folk medicine in Brazil, Bolivia, Mexico and the United States of America [USA] (9-13). Research has shown its potential medicinal value in treating hypoglycaemia, rheumatoid arthritis and liver infections (14) and the ground breaking anti-cancer effect of this plant was discovered in 2007 (15). In addition, research has identified several phytochemicals from the plant and these include: cycloartane triterpenoids, pentacyclic triterpenes, sterols and flavonoids $(16,17)$.

This paper describes the anti-cancer properties of the Jamaican ball moss.

\section{METHODS}

\section{Plant collection and preparation}

$T$ recurvata (Fig. 1) was collected from trees and electrical poles in Kingston, Jamaica. A voucher specimen of the plant was identified at the Institute of Jamaica Herbarium where it was deposited with accession number: IJ 3411. The collected biomass was air dried under shade and pulverized into powder.

\section{Extraction and isolation}

$1 \mathrm{~kg}$ of ball moss biomass was extracted twice with 5L of methanol. The filtrate was dried in a rotavapor to obtain a dark green residue $(16.3 \mathrm{~g})$. The extract was stored in a refrigerator at $4{ }^{\circ} \mathrm{C}$ until needed for use in the bioassay.

\section{Biological assay}

Cell lines and culture medium

Five different histogenic tumours (prostate cancer, PC-3; breast cancer, BC; Kaposi sarcoma, KS; B-16 melanoma and a B-cell lymphoma) from a transgenic mouse strain were used in the study. The cell lines were obtained from American Type Culture Collection (ATCC) [Manassas, VA, USA] or from in-house cultures, specifically KS and the Bcell lymphoma from an HIV-1 transgenic mouse. The cells were maintained in minimum essential media supplemented with $10 \%$ fetal calf serum, $1 \%$ L-glutamine, $2 \%$ penicillinstreptomycin, and $0.2 \%$ gentamicin at $37{ }^{\circ} \mathrm{C}$ with $5 \% \mathrm{CO}_{2}$. Cell death/viability was measured by the trypan blue exclusion assay protocol (18).

\section{Extract preparation and treatment}

The dried crude extract of ball moss formulated was in dimethyl sulfoxide (DMSO) and normal saline (2:8). The drug concentration was $1 \mathrm{mg} / \mathrm{ml}$ and each mouse was administered $0.2 \mathrm{ml}$, giving a dose of $10 \mathrm{mg} / \mathrm{kg}$. The vehicle was prepared using the same diluent concentrations without the extract.

In vivo maximum tolerable dose study

Mice used were purchased from Harlan Sprague Dawley (Indianapolis, Indiana) and maintained in a pathogen-free environment in the Institute of Human Virology Animal Facility in the University of Maryland School of Medicine. All experiments involving mice were approved by the Institutional Animal Care and Use Committee at the University of Maryland School of Medicine. To determine the maximum tolerable dose (MTD) for the experiment, 15 nude mice were divided into three equal groups. Two of the groups were respectively treated with $100 \mathrm{mg} / \mathrm{kg}$ and $200 \mathrm{mg} / \mathrm{kg}$ IP using a crude ball moss extract daily for five days and the third group was treated with the vehicle control. The MTD was found to be $>200 \mathrm{mg} / \mathrm{kg}$ and it was thus determined that it was safe to use any of the two concentrations or lower in the efficacy study.

\section{In vivo efficacy study}

From the above MTD studies, we used the $10 \mathrm{mg} / \mathrm{kg}$ for treatment of the tumours in the mice. All mice were maintained as described above. Thirty nu/nu (NIH) mice, four to six weeks old were inoculated with $3 \times 10^{6}$ Kaposi sarcoma cancer cells in 33\% matrigel $/ 67 \%$ media with no fetal calf serum (FCS). When tumours reached $\sim 100 \mathrm{~mm}^{3}$, the mice were divided into two groups of eight mice each so that the 
mean tumour volume was similar. Dosing was initiated on the day of sorting. Mice were dosed daily for a total of 30 days orally. The body weight of mice was taken alongside tumour volumes twice a week and the tumour volumes determined using the following formula:

$\mathrm{L} \mathrm{x} \mathrm{W}^{2} / 2(\mathrm{~L}=$ tumour length; $\mathrm{W}=$ tumour width $)$

\section{Assessment of apoptosis}

The Apoptag kit (Intergen, Purchase, NY) was used to determine effect on apoptosis according to the manufacturer's instructions. After light counterstaining with haematoxylin (H\&E), nuclei that stained brown were scored as positive for apoptosis and those that stained blue were scored as negative.

\section{RESULTS}

\section{In vitro anti-proliferation activity}

The results of the in vitro anti-proliferation assay results are presented in Fig. 2. All the five cancer cell lines showed

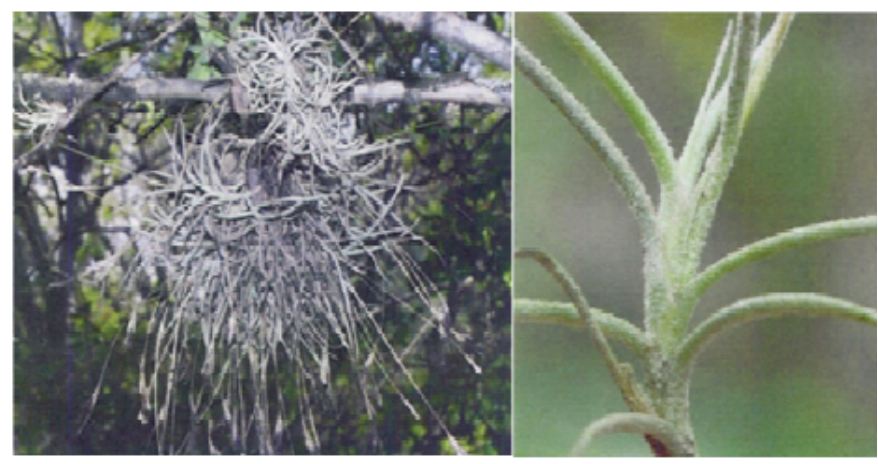

Fig. 1: Tillandsia recurvata in its natural habitat growing on plants (left) and young shoot of the plant (right).

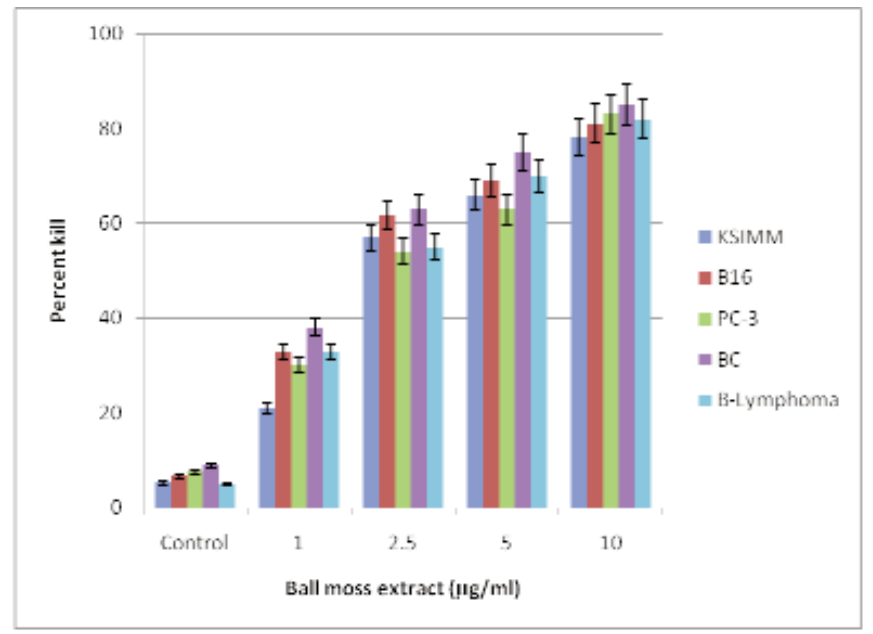

Fig. 2: Anti-proliferation activity of ball moss on different cancer cell lines $(\mathrm{KSIMM}=$ Kaposi sarcoma; B16 = mouse melanoma; PC-3 $=$ prostate cancer; $\mathrm{BC}=$ breast cancer and $\mathrm{B}$-cell lymphoma) in vitro, using the trypan blue assay after 48 hours. At least $50 \%$ of the cells were inhibited from proliferation at the concentration of $2.5 \mu \mathrm{g} / \mathrm{ml}$. Breast cancer was the most sensitive cell line. sensitivity to the ball moss extract with the breast cancer cell line showing the most sensitivity and the Kaposi sarcoma cell line showing lower sensitivity.

\section{Apoptosis assay}

The five tumours that were passed in vivo were tested and on histological examination, all tumours showed necrosis on H\&E. Histologically, using the immunohistochemical staining (Apoptag), all tumours showed clear evidence of brown staining, demonstrating apoptosis. A representative sample of the histology and the Apoptag staining are demonstrated in Fig. 3.

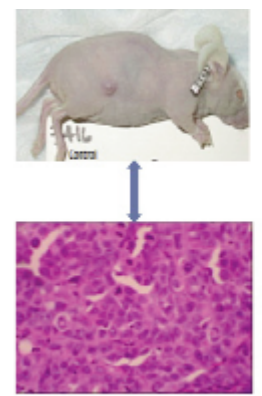

A

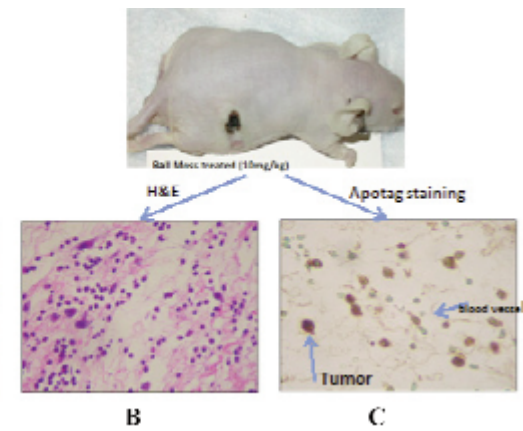

C
Fig. 3: The histological analysis of Kaposi sarcoma (KS) tumour growth of the control and experimental group. The haematoxylin section in the control mice (A), shows the typical microscopic growth of KS noting numerous blood vessels (note the highly angiogenic vessels). In the treatment group (B), note the necrosis of the tumour with loss of blood vessels. In treatment group (C), note the brown staining tumour cells and the thin endothelial cells (indicating apoptosis).

\section{In vivo anti-tumour activity}

Treating of mice injected with Kaposi sarcoma cells resulted in significant arrest of tumour growth compared to control $(p$ $<0.05$ ). Figure 4 presents the results of the in vivo efficacy

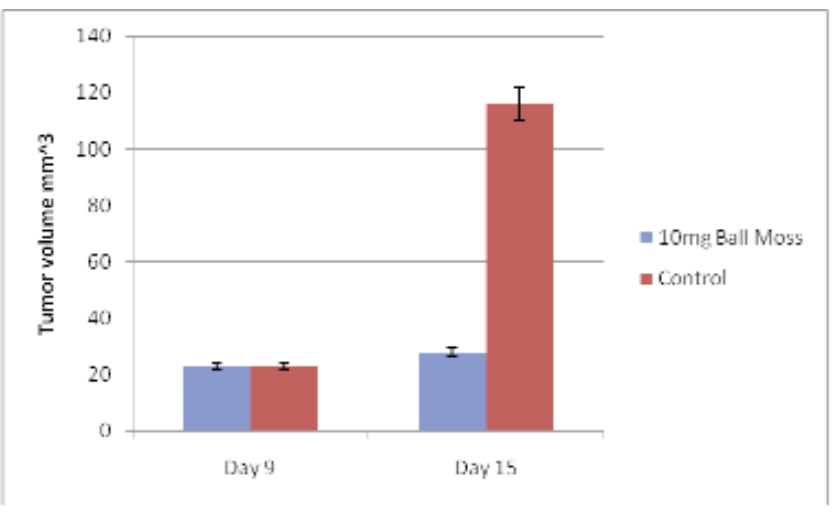

Fig. 4: Effect of ball moss extract on Kaposi sarcoma in vivo in nude mice. Nude mice were injected with $3 \times 10^{6}$ Kaposi sarcoma cells subcutaneously on the right flank. Tumours were monitored and measurements started once visible signs of tumour growth were observed. The ball moss group was treated by IP injection of 10 $\mathrm{mg} / \mathrm{kg}$ of extract. By day 15 , most of the tumours in the treatment group had regressed or dried up while the control group tumours continued to grow. 
studies. The concentration used was selected based on the MTD study results where ball moss was found to be safe at up to $200 \mathrm{mg} / \mathrm{kg}$ by oral gavage. Haematoxylin staining of tumour cells harvested from treated and control mice showed significant difference in cell morphology.

\section{DISCUSSION}

On the basis of the observed in vitro and in vivo activities of ball moss, our hypothesis that this plant possesses unique compounds based on the environment that it grows in has been confirmed in these preliminary set of studies. The plant extract has demonstrated activity against five major cancer cell lines in vitro as well as in vivo activity against Kaposi sarcoma which is one of the HIV-related cancers currently plaguing the AIDS community.

Efforts to determine the mechanism of action has indicated that ball moss exhibit its activity against cancer cells by triggering the process of apoptosis (Fig. 3). Apoptosis or programmed cell death involves the activation of a set of cysteine proteases known as "caspases" (19).

The study presented here demonstrated the anti-cancer properties of $T$ recurvata extract against tumours of different histogenic origins. This observation of a crude extract showing strong anti-cancer properties supports the importance of studying this plant with unique bioactive metabolites. We are currently in the process of determining the specific compound(s) responsible for the anti-cancer activity demonstrated by the plant extract in this study.

\section{ACKNOWLEDGEMENT}

The authors are grateful to Hieu Tran of the Institute of Human Virology and Dr Rena Lapidus of the Translational Core of the Greenebaum Cancer Center, University of Maryland School of Medicine for assisting with the study. We are also grateful to Mr Keron Campbell and Ms Shelly Ann Powell for assisting with the collection, identification and extraction of the plant material.

\section{REFERENCES}

1. Koehn FE, Carter GT. The evolving role of natural products in drug discovery. Nat Rev Drug Discovery 2005; 4: 206-20.

2. Lam KS. New aspects of natural products in drug discovery. Trends Microbiol 2007; 15: 279-89.

3. Harvey AL. Natural products in drug discovery. Drug Discovery Today 2008; 13: 894-901.

4. Cragg GM, Newman DJ, Snader KM. Natural products in drug discovery and development. Journal of Natural Products 1997; 60: 52-60.

5. Ji H-F, Li X-J, Zhang H-Y. Natural products and drug discovery. Can thousands of years of ancient medical knowledge lead us to new and powerful drug combinations in the fight against cancer and dementia? EMBO Rep 2009; 10: 194-200.

6. Demain AL, Zhang L. Natural products and drug discovery. In: Zhang L, Demain AL, eds. Natural products: drug discovery and therapeutic medicines. Totowa, New Jersey: Humana Press; 2005: 3-29.

7. Cragg GM, Newman DJ. Plants as a source of anti-cancer agents. J Ethnopharmacol 2005; 100: 72-9.

8. Benzing DH. The biology of the bromeliads. Eureka, California: Mad River Press; 1980.

9. Alonso Paz E, Cerdeiras MP, Fernandez J, Ferreira F, Moyna P, Soubes $\mathrm{M}$ et al. Screening of Uruguayan medicinal plants for antimicrobial activity. J Ethnopharmacol 1995; 45: 67-70.

10. Bourdy G, Chāvez de Michel L, Roca-Coulthard A. Pharmacopoeia in a shamanistic society: the Izoceno-Guaranı (Bolivian Chaco). J Ethnopharmacol 2004; 91: 189-208.

11. Adonizio AL, Downum K, Bennett BC, Mathee K. Anti-quorum sensing activity of medicinal plants in southern Florida. J Ethnopharmacol 2006; 105: 427-35.

12. Agra MF, Baracho GS, Nurit K, Basilio IJLD, Coelho VPM. Medicinal and poisonous diversity of the flora of "Cariri Paraibano", Brazil. J Ethnopharmacol 2007; 111: 383-95.

13. Smith-Oka V. Plants used for reproductive health by Nahua women in Northern Veracruz, Mexico. Economic Botany 2008; 62: 604-14.

14. Witherup K, McLaughlin J, Judd R, Ziegler M, Medon P, Keller W. Identification of 3-hydroxy-3-methylglutaric acid (HMG) as a hypoglycemic principle of Spanish moss (Tillandsia usneoides). Journal of Natural Products 1995; 58: 1285-90.

15. Lowe H. Anti-tumour and anti-inflammatory extracts of plant biomass and their uses. Google Patents; 2010.

16. de Queiroga MA, de Andrade LM, Florêncio KC, de Fátima Agra M, da Silva MS, Barbosa-Filho JM et al. Chemical constituents from Tillandsia recurvata. Fitoterapia 2004; 75: 423-5.

17. Cabrera GM, Seldes AM. Hydroperoxycycloartanes from Tillandsia recurvata. Journal of Natural Products 1995; 58: 1920-4.

18. Altman SA, Randers L, Rao G. Comparison of trypan blue dye exclusion and fluorometric assays for mammalian cell viability determinations. Biotechnol Prog 1993; 9: 671-74.

19. Alam JJ. Apoptosis: target for novel drugs. Trends Biotechnol 2003; 21: $479-83$. 